\title{
Comparative Growth Performance of Oreochromis Hybrids and Selectively-Bred Strain $\left(\mathrm{F}_{8}\right)$ in Malawi
}

\author{
Daud Kassam ${ }^{1} \&$ Marcus Sangazi ${ }^{1}$ \\ 1 Aquaculture and Fisheries Science Department, Bunda Campus, Lilongwe University of Agriculture and \\ Natural Resources, P.O. Box 219, Lilongwe, Malawi \\ Correspondence: Daud Kassam, Aquaculture and Fisheries Science Department, Bunda Campus, Lilongwe \\ University of Agriculture and Natural Resources, P.O. Box 219, Lilongwe, Malawi. Tel: 265-999-103-246. \\ E-mail: dkassam@bunda.luanar.mw
}

\author{
Received: May 3, 2016 Accepted: July 1, 2016 Online Published: July 13, 2016 \\ doi:10.5539/sar.v5n4p13 URL: http://dx.doi.org/10.5539/sar.v5n4p13
}

\begin{abstract}
Most fish farmers in Malawi culture unimproved fish strains whose growth is slow and mature while still small. Four strains of Oreochromis, namely; selectively-bred/improved $O$. shiranus $\left(\mathrm{F}_{8}\right)$, two reciprocal $\mathrm{F}_{1}$ Oreochromis hybrids, and $O$. karongae as a control (mean weight $2.5 \pm 0.7 \mathrm{~g}$ ) were stocked at a density of $5 \mathrm{fish} / \mathrm{m}^{2}$ in $9 \mathrm{~m}^{2}$ hapas replicated three times, and cultured for 90 days at Bunda Fish Farm. Fish were fed twice a day with feed formulated using maize bran and soybean containing $30 \%$ crude protein throughout the experimental period. The final mean weights were significantly different $(\mathrm{p}<0.05)$ across the treatments whereby; hybrid O. shiranus (male) X O. karongae (female) was $12.09 \mathrm{~g}$, hybrid O. shiranus (female) X O. karongae (male) was $9.72 \mathrm{~g}$, improved $O$. shiranus $\left(\mathrm{F}_{8}\right)$ registered $9.23 \mathrm{~g}$, and $O$. karongae was the least with $9.00 \mathrm{~g}$. Apparent food conversion ratio was also statistically different $(\mathrm{p}<0.05)$ across the treatments whereby; O. karongae was 3.63, hybrid $O$. shiranus (female) X $O$. karongae (male) was 3.25, improved $O$. shiranus $\left(\mathrm{F}_{8}\right)$ was 3.16 and hybrid $O$. shiranus (male) X O. karongae (female) was lowest with 2.26. There were no significant differences on the water quality parameters across the treatments throughout the experimental period and were within the required ranges for growth and survival of tilapias fish species. The results suggest that Oreochromis hybrids may be suitable candidates for aquaculture in terms of production as they performed better than the improved O. shiranus and the control O. karongae.
\end{abstract}

Keywords: food conversion ratio, hybridization, improved strain, Oreochromis

\section{Introduction}

Fish provides about $72 \%$ of animal protein and is a very important source of food and income for Malawians (Ecker \& Qaim, 2011). High population growth and alarming levels of poverty in Malawi have caused an unprecedented overexploitation of freshwater ecosystem fisheries (Jamu, Banda, Njaya, \& Hecky, 2011). Moreover, the combined effect of anthropogenic activities and urban extension have substantially reduced the natural fish habitat through siltation and water bodies' removal, resulting in a severe decrease in fisheries yield. Therefore, capture fisheries do not seem to be sustainable and aquaculture is the best alternative in sustaining fish supply to the population due to its potential to grow because land and water resources are still abundant. In order to enhance fish production, the Government of Malawi developed National Aquaculture Strategic Plan (NASP) in 2005 to spearhead the development of aquaculture. While there have been several initiatives to promote aquaculture development, the Presidential Initiative for Aquaculture Development (PIAD) stands out as the major initiative which targeted to raise by 10 folds (within 5 years) the national fish stock production, sustaining the local consumption and exports.

In Malawi, Tilapia rendalli, Oreochromis shiranus, Oreochromis karongae and Clarias gariepinus are some of the major fish species cultured by farmers in earthen ponds. Growth and survival rates in ponds are the most common complaints from farmers for these indigenous tilapia species (Maluwa \& Gjerde, 2007). The national regulatory authority which define the legislation and laws in the fishery sector, promote a sustainable aquaculture through a close partnership between the public and private actors and make illegal some practices likes exotic species introduction. Thus, the improvement of the indigenous species' growth performance and survival rates using the available technology has become the main target (Ross, Martinez Palacios, \& Morales, 
2008). Researchers mainly focused on the genetic improvement of fish species life-history traits, in particular, $O$. shiranus, the predominant farmed species, naturally characterized by a slow growth rate and small maturity-size. Fast growing species have a lower production cost and a higher commercial value than small species (Andrew, Weyl, \& Andrew, 2003).

Growth performance tests done on O. shiranus (M'balaka, Kassam, \& Rusuwa, 2012) and O. niloticus (Olesen, Gjedrem, Bentsen, Gjerde, \& Rye, 2003) showed an improvement of $25.2 \%$ and $101 \%$ after 6 and 5 generations, respectively, compared to unimproved strains. The relative lower performance noted in the $O$. shiranus growth rate, issued from the selective breeding process, may potentially be corrected by hybridization. This argument is supported by the observations of Munthali (2011, unpublished report), suggesting that Oreochromis hybrids grow better than its parental lines. However, recommendations to farmers cannot be issued without resolving the scientific gap relative to the comparative growth performance between the selectively bred $\left(\mathrm{F}_{8}\right)$ O. shiranus strain and the hybridized one. Thus, the objective of the present paper is to accurately determine and compare the growth performance and survival rates of these two strains.

\section{Materials and Methods}

\subsection{Breeding Phase}

The experiment was conducted at Bunda fish farm. Four treatments were set using hapas of $9 \mathrm{~m}^{2}$ fixed in a pond of $700 \mathrm{~m}^{2}$ and each treatment was replicated twice. $O$. shiranus and $O$. karongae were reciprocally hybridized, a male of one species was crossed with a female of another species and vice versa. A single crossing was made between the improved strains issued from the seventh generation of $O$. shiranus. Finally a male and a female of $O$. karongae were crossed and used as controls. Broodstock of average weight $120 \mathrm{~g}$ were stocked at sex ratio of one male for three females. The broodstock were fed with a diet formulated from a mixture of maize bran and soybean with $29 \%$ crude protein, using the Pearson's square method. As a supplement, the natural food were boosted by application of chicken manure to the pond at the rate of $500 \mathrm{~kg} / \mathrm{ha} / \mathrm{week}$ (Kang'ombe \& Brown, 2008). The fish were hand fed twice a day at $5 \%$ body weight in line with recommendations of Lovell (1989). Fry were removed from the breeding hapas to fry rearing tanks every two weeks.

\subsection{Grow out Phase}

Fingerlings of mixed sex, with body weight ranging from 2.4 to $2.6 \pm 0.7 \mathrm{~g}$, from the rearing tanks were stocked in $9 \mathrm{~m}^{2}$ hapas at density of $5 \mathrm{fish} / \mathrm{m}^{2}$. A total of 135 fingerlings from each treatment was selected and $45 \mathrm{fish} / \mathrm{hapa}$ was randomly stocked. Feeding was twice every day at $5 \%$ body weight. A completely randomized design (CRD) was used to allocate four treatments, replicated three times each in $700 \mathrm{~m}^{2}$ pond with the following treatments; hybrid $O$. shiranus (male) X $O$. karongae (female), hybrid $O$. shiranus (female) X $O$. karongae (male), improved $O$. shiranus $\left(\mathrm{F}_{8}\right)$ and pure $O$. karongae.

\subsection{Water Quality Parameters}

Water quality parameters were rigorously monitored before and during the experiment. The physical and chemical properties of the water were surveilled using appropriate devices and the titration method was used to determine the ammonia concentration. Measurements were conducted twice a day during the morning and in the afternoon.

\subsection{Data Collection and Analysis}

Data on growth were collected every fortnight whereby fish were weighed using an electrical analytical balance calibrated to $0.01 \mathrm{~g}$ and total length $(\mathrm{mm})$ measured using a stainless steel topped measuring board. Specific growth rate (SGR\%/day) was calculated using the following formula:

Specific growth rate (SGR);

$$
\% \mathrm{SGR}=\frac{\ln \mathrm{W} 1-\ln \mathrm{W} 0}{\boldsymbol{t} 1-\boldsymbol{t o}} \mathrm{X} 100
$$

Where:

$\mathrm{W}_{1}=$ final mean weight $(\mathrm{g})$ of fish

$\mathrm{W}_{0}=$ initial mean weight $(\mathrm{g})$ of fish at stocking time

$\mathrm{t}=$ time in days

$\ln =$ natural $\log$

Survival rate

Survival rate was determined using the following formula: 


$$
\text { Survival rate }(\%)=\frac{\text { Numberoffishattheendof experiment }}{\text { Numberof fishatthestartof theexperiment }} \times 100
$$

Food utilization efficiency

Apparent food conversion ratio (AFCR) was determined using the formula below

$$
\text { AFCR }=\frac{\text { weight of dry feed given to the fish }(\mathrm{kg})}{\text { weight gained by the fish }(\mathrm{kg})}
$$

Data was analyzed using Genstat statistical package $\left(15^{\text {th }}\right.$ edition); using One-way Analysis of Variance (ANOVA) at 95\% level of confidence. When ANOVA revealed overall significant difference on the growth parameters, planned contrasts were used to separate the means among the treatments.

\section{Results}

The initial mean weights of the four treatments ranged from $2.5 \pm 0.07 \mathrm{~g}$ to $2.64 \pm 0.07 \mathrm{~g}$, with no significant differences whilst the final mean weights differed significantly among the treatments $(\mathrm{p}<0.05$, Table 1$)$. The final mean weight of the hybrid O. shiranus (male) X O. karongae (female) which was $12.09 \mathrm{~g}$, was significantly higher than the other three strains $(\mathrm{p}<0.001)$, whereby the final mean weight of the hybrid $O$. shiranus (female) $\mathrm{X} O$. karongae (male) was $9.72 \mathrm{~g}$, improved O. shiranus $\left(\mathrm{F}_{8}\right)$ was $9.23 \mathrm{~g}$ and $O$. karongae was $9.00 \mathrm{~g}$ and were not statistically different (Table $1 \& 2$ ).

Specific growth rates (SGR \%/day) were significantly different for fish treatments $(\mathrm{p}<0.05$, Table 1$)$, hybrid $O$. shiranus (male) X O. karongae (female) had higher specific growth rate (1.72\%) while hybrid O. shiranus (female) X O. karongae (male) (1.52\%), improved O. shiranus $\left(\mathrm{F}_{8}\right)(1.50 \%)$ and $O$. karongae $(1.33 \%)$ were not statistically different $(\mathrm{p}>0.05)$.

Planned contrast showed that apparent food conversion ratio (AFCR) for the hybrid O. shiranus (male) X O. karongae (female) which registered 2.26, differed significantly from the other treatments $(\mathrm{p}<0.001$, Table 1$)$. The improved O. shiranus $\left(\mathrm{F}_{8}\right)$ had 3.25, hybrid O. shiranus (female) X O. karongae (male) had 3.16 and $O$. karongae had 3.63; there was no statistical difference among the later three treatments. Fish survival rates were not significantly different across the four treatments ( $>0.05$, Table 1). The hybrid O. shiranus (male) X O. karongae (female) was $98.5 \%$, improved $O$. shiranus $\left(\mathrm{F}_{8}\right)$ was $91.9 \%$, hybrid $O$. shiranus (female) X O. karongae (male) was $95.6 \%$, whilst pure $O$. karongae was $86.7 \%$ (Table 2).

Table 1. Values of contrast and p-value of initial and final mean weights, specific growth rate (SGR), apparent

\begin{tabular}{|c|c|c|c|c|c|}
\hline \multirow[b]{2}{*}{ Contrast } & \multicolumn{5}{|c|}{ Parameter (mean difference $\left.\mu_{i}-\mu_{j}\right)$} \\
\hline & Initial weight $(\mathrm{g})$ & Final weight (g) & SGR\%/day & AFCR & Survival rate $(\%)$ \\
\hline $\mathrm{OS}\left(\delta^{\lambda}\right) \mathrm{X} \mathrm{OK}(q)-\mathrm{OS}\left(\mathrm{F}_{8}\right)$ & 0.00 & 2.86 & 0.22 & 0.90 & 6.6 \\
\hline P-value & 0.175 & $<0.001$ & 0.018 & $<0.001$ & 0.590 \\
\hline $\begin{array}{l}\mathrm{OS}\left(\delta^{\lambda}\right) \mathrm{X} \mathrm{OK}(q)-\mathrm{OS}(q) \mathrm{X} \\
\mathrm{OK}\left(\delta^{\lambda}\right)\end{array}$ & 0.10 & 2.37 & 0.20 & 0.99 & 2.6 \\
\hline P-value & 0.121 & $<0.001$ & 0.028 & $<0.001$ & 0.475 \\
\hline $\mathrm{OS}(ð) \mathrm{X} \mathrm{OK}(q)-\mathrm{Ok}$ & 0.10 & 3.09 & 0.39 & 1.37 & 11.8 \\
\hline p-value & 0.697 & $<0.001$ & 0.004 & $<0.001$ & 0.175 \\
\hline $\left.\mathrm{OS}\left(\mathrm{F}_{8}\right)-\mathrm{OS}(+)\right) \mathrm{X} \mathrm{OK}\left(\delta^{\Uparrow}\right)$ & 0.10 & 0.49 & 0.02 & 0.09 & 3.7 \\
\hline p-value & 0.846 & 0.377 & 1.213 & 0.776 & 0.226 \\
\hline $\mathrm{OS}\left(\mathrm{F}_{8}\right)-\mathrm{OK}$ & 0.10 & 0.23 & 0.17 & 0.47 & 5.2 \\
\hline p-value & 0.082 & 0.744 & 0.213 & 0.089 & 0.060 \\
\hline $\mathrm{OS}(+) \mathrm{X} \mathrm{OK}\left(0^{\Uparrow}\right)-\mathrm{OK}$ & 0.2 & 0.72 & 0.19 & 0.38 & 8.9 \\
\hline p-value & 0.053 & 0.227 & 0.013 & 0.155 & 0.408 \\
\hline
\end{tabular}
food conversion ratio (AFCR), and survival rate of fish

The mean difference is significant at the 0.05 level. 
Table 2. Initial and final mean weights, specific growth rate (SGR), apparent feed conversion ratio (AFCR), and survival rate of fish

\begin{tabular}{lllll}
\hline \multicolumn{5}{l}{ Treatment } \\
\hline Parameter & $\boldsymbol{O S}\left({ }^{\Uparrow}\right) \mathbf{X ~} \boldsymbol{O K}(+)$ & $\boldsymbol{O S}\left(\mathrm{F}_{\mathbf{8}}\right)$ & $\boldsymbol{O S}(+) \mathbf{X} \boldsymbol{O K}\left({ }^{\Uparrow}\right)$ & $\boldsymbol{O k}$ \\
\hline Initial mean weight $(\mathrm{g})$ & 2.5 & 2.5 & 2.4 & 2.6 \\
Final mean weight $(\mathrm{g})$ & 12.09 & 9.23 & 9.72 & 9.00 \\
SGR (\%/day) & 1.72 & 1.50 & 1.52 & 1.33 \\
AFCR & 2.26 & 3.16 & 3.25 & 3.63 \\
Survival rate (\%) & 98.5 & 91.9 & 95.6 & 86.7 \\
\hline
\end{tabular}

Water quality parameters in the pond were within the required ranges for the growth of tilapia fish species during the experiment. There were no significant differences for measured water quality parameters among treatments throughout the experimental period $(P>0.05)$. Mean water temperature ranged from $24.74 \pm 0.2^{\circ} \mathrm{C}$ to $28.23 \pm$ $0.2^{\circ} \mathrm{C}$ across the treatments. Dissolved oxygen ranged from 4.64 to $6.82 \mathrm{mg} / L$, the $\mathrm{pH}$ between 8.10 and 8.41 , ammonia ranged from 0.061 to $0.087 \mathrm{mg} / \mathrm{L}$ throughout the experimental period (Table 3).

Table 3. Water quality parameters (mean $\pm \mathrm{SE}$ )

\begin{tabular}{|c|c|c|c|c|c|}
\hline & \multicolumn{4}{|l|}{ TREATMENT } & \multirow{2}{*}{$\begin{array}{l}\text { DESIRABLE } \\
\text { LIMITS }\end{array}$} \\
\hline PARAMETER & OS( $\left(^{\lambda}\right)$ X OK( $(+)$ & $\operatorname{OS}\left(F_{8}\right)$ & OS( $(+)$ X OK $\left({ }^{\lambda}\right)$ & OK & \\
\hline \multirow[t]{2}{*}{ Temperature $\left({ }^{\circ} \mathrm{C}\right)$} & Am $24.7 \pm 0.5 \mathrm{a}$ & $25.1 \pm 0.5 \mathrm{a}$ & $25.2 \pm 0.5 \mathrm{a}$ & $25.2 \pm 0.5 \mathrm{a}$ & \multirow[t]{2}{*}{$20-30$} \\
\hline & $\operatorname{Pm} 28.1 \pm 0.7 \mathrm{a}$ & $28.3 \pm 0.7 \mathrm{a}$ & $27.9 \pm 0.6 \mathrm{a}$ & $28.2 \pm 0.7 \mathrm{a}$ & \\
\hline \multirow[t]{2}{*}{$\mathrm{DO}(\mathrm{mg} / \mathrm{L})$} & $\operatorname{Am~} 4.7 \pm 0.4 \mathrm{a}$ & $4.9 \pm 0.4 a$ & $4.6 \pm 0.4 a$ & $4.8 \pm 0.4 a$ & \multirow[t]{2}{*}{5} \\
\hline & $\operatorname{Pm} 6.8 \pm 0.2 \mathrm{a}$ & $6.7 \pm 0.2 \mathrm{a}$ & $6.0 \pm 0.2 \mathrm{a}$ & $6.8 \pm 0.2 \mathrm{a}$ & \\
\hline \multirow[t]{2}{*}{$\mathrm{pH}$} & $\operatorname{Am~} 8.1 \pm 0.2 \mathrm{a}$ & $8.2 \pm 0.2 \mathrm{a}$ & $8.1 \pm 0.2 \mathrm{a}$ & $8.1 \pm 0.3 \mathrm{a}$ & \multirow[t]{2}{*}{$6.5-9$} \\
\hline & $\operatorname{Pm} 8.3 \pm 0.2 \mathrm{a}$ & $8.4 \pm 0.2 \mathrm{a}$ & $8.4 \pm 0.2 \mathrm{a}$ & $8.3 \pm 0.2 \mathrm{a}$ & \\
\hline Ammonia (mg/L) & $0.087 \pm 0.03 \mathrm{a}$ & $0.061 \pm 0.02 \mathrm{a}$ & $0.073 \pm 0.03 a$ & $0.062 \pm 0.02 \mathrm{a}$ & $<0.1$ \\
\hline
\end{tabular}

Figures in rows with same letters are not significantly different.

\section{Discussion}

This study revealed that the growth of hybrid $O$. shiranus (male) X $O$. karongae (female), in terms of the weight gained and specific growth rate (SGR), were significantly higher than that of the improved $O$. shiranus, $O$. karongae and hybrid $O$. shiranus (female) X $O$. karongae (male). This higher growth performance of the hybrid strain may be attributed to the genetic superiority of this strain and, if so, lends support to the fact that hybrid tilapia are preferred because of their significant high yield and survival (Mair, 2007). The results can also be supported by the fact that hybrid individuals acquire traits from both parents; therefore higher growth rate and other growth parameters in the hybrids may be as a result of combined traits from both parents.

The improved O. shiranus strain has shown to start spawning at less than $10 \mathrm{~g}$ (in this study at $8.7 \mathrm{~g}$ ), yet the demand for the local tilapias is high for large sizes like 150-200g (Worldfish Centre, 2010). This early sexual maturation in production ponds can significantly reduce fish yield, as maturing fish can become aggressive, stop growing, and become more susceptible to disease. In this study, there was no fish observed to start spawning throughout the experimental period from both the reciprocal hybrids and $O$. karongae. The late maturity of the Oreochromis hybrids, resonate well with other findings that have reported that tilapia hybrids attain larger sizes at harvest (Mair, 2007). In terms of genetic gain over the control, this study has shown a $34 \%$ genetic gain, which is similar to what Munthali (2011) found, though in that study it ranged from 34-49\% depending on the pair crossed. The results of this study also showed that there was no significant difference in fish survival among the strains, above $90 \%$ for reciprocal $\mathrm{F}_{1}$ hybrids and improved $O$. shiranus and $86.7 \%$ for $O$. karongae. This may 
be attributed to the fact that tilapias are hard fish species, tolerate harsh conditions of water such as low dissolved oxygen of about $0.6 \mathrm{ml} / 1$ and wide range of temperatures 16 to $42{ }^{\circ} \mathrm{C}$, as such, tilapias thrive in most fish ponds of Malawian farmers.

One of the most significant growth parameters in aquaculture is the efficiency of the fish to convert food into flesh; this was determined as apparent food conversion ratio (AFCR).The hybrid $O$. shiranus (male) $\mathrm{X} O$. karongae (female) strain had lowest apparent food conversion ratio (AFCR); thus more efficient at utilizing feed and growing better than the improved $O$. shiranus, hybrid $O$. shiranus (female) X $O$. karongae (male) and $O$. karongae.

\section{Conclusion}

This study revealed that the growth performance of Oreochromis hybrid O. shiranus (male) X O. karongae (female), in terms of the weight gained and specific growth rate (SGR), were highest coupled with survival rate which was above $85 \%$. The hybrids which performed better had lowest AFCR, thus more efficient in food utilization. Therefore, this study reveals that hybridization is more productive than the selective breeding program as improvement of the indigenous fish species is concerned.

\section{References}

Andrew, T. G., Weyl, O. L. F., \& Andrew, M. (2003). Aquaculture master plan development in Malawi: Socioeconomic survey report.

Ecker, O., \& Qaim, M. (2011). Analyzing nutritional impacts of policies: an empirical study for Malawi. World Dev., 39, 412-428. http://dx.doi.org/10.1016/j.worlddev.2010.08.002

Jamu, D., Banda, M., Njaya, F., \& Hecky, R. E. (2011). Challenges to sustainable management of the lakes of Malawi. J. Great Lakes Res., 37, 3-14. http://dx.doi.org/10.1016/j.jglr.2010.11.017

Kang'ombe, J., \& Brown, J. A. (2008). Effect of using low-protein diets in semi-intensive pond cage culture of tilapia, Tilapia rendalli (Boulenger). J. Appl Aquac., 20, 243-255. http://dx.doi.org/10.1080/10454430802498203

Lovell, T. (1989). Nutrition and feeding of fish. Van Nostrand Reinhold, New York, USA. http://dx.doi.org/10.1007/978-1-4757-1174-5

Mair, G. C. (2007). Genetics and breeding in seed supply for inland aquaculture. In M. G. Bondad-Reantaso (ed.), Assessment of freshwater fish seed resources for sustainable aquaculture (pp. 519-547). FAO Fisheries Technical Paper. No. 501. Rome.

Malawi Government. (2001a). National Fisheries and Aquaculture Policy, Department of Fisheries, Ministry of Natural Resources and Environmental Affairs, Lilongwe, Malawi.

Malawi Government. (2011b). Guidelines for Tilapia hatchery operators in Malawi, Ministry of Agriculture and food Security, Lilongwe, Malawi.

Maluwa, A. O., \& Gjerde, B. (2007). Genetic evaluation of four strains of Oreochromis shiranus for harvest body weight in a diallel cross. Aquac., 259, 28-37. http://dx.doi.org/10.1016/j.aquaculture.2006.06.003

M'balaka, M., Kassam, D., \& Rusuwa, B. (2012). The effect of stocking density on the growth and survival of improved and unimproved strains of Oreochromis shiranus. Egypt. J. Aqua. Res., 38, 205-211. http://dx.doi.org/10.1016/j.ejar.2012.12.013

Munthali K. (2011). Growth performance and survival of hybrids between Oreochromis karongae and Oreochromis shiranus. Aquaculture and Fisheries Science Department, Bunda College, Lilongwe, Malawi.

NASP. (2005). Ministry of Mine, Natural Resources and environment, Department of Fisheries, Zomba, Malawi No: 28 .

Olesen, I., Gjedrem, T., Bentsen, H. B., Gjerde, B., \& Rye, M. (2003). Breeding programs for sustainable aquaculture. J. Appl. Aquac., 13, 179-204. http://dx.doi.org/10.1300/J028v13n03_01

Ross, L. G., Martinez Palacios, C. A., \& Morales, E. J. (2008). Developing native fish species for aquaculture: the interacting demands of biodiversity, sustainable aquaculture and livelihoods. Aquac. Res., 39, 675-683. http://dx.doi.org/10.1111/j.1365-2109.2008.01920.x

World Fish Center. (2010). Cage Aquaculture in Malawi, Briefing note 2119 World Fish Center. 


\section{Copyrights}

Copyright for this article is retained by the author(s), with first publication rights granted to the journal.

This is an open-access article distributed under the terms and conditions of the Creative Commons Attribution license (http://creativecommons.org/licenses/by/4.0/). 